\title{
Studies of the biosynthesis of tentoxin by Alternaria alternata
}

\author{
Kerstin Ramm, Michael Ramm, Bernd Liebermann and Gerhard Reuter
}

Author for correspondence: Kerstin Ramm. Tel: +49 3641 28602. Fax: +49364123604.

Department of Microbiology, FriedrichSchiller-University, Wöllnitzer Straße 7, Jena 07749, Germany
Biosynthesis of the phytotoxin, tentoxin, its regulation and the enzymic synthesis steps were studied in vivo and in vitro. The physiology of biosynthesis of tentoxin in vivo was investigated by using sections of mycelial mats incubated in buffer. Differentiated mycelia could be studied under defined conditions. The de novo synthesis of tentoxin was measured by incorporation of $\left[\mathrm{U}-{ }^{-14} \mathrm{C}\right]$ leucine into tentoxin. The investigation system was stable for $10 \mathrm{~h}$. Biosynthesis and the growth of biomass started before day 5 of culture, with the maximum between days 9 and 12. After this, biosynthesis quickly declined. pH values about 7 were optimal, and pH values above and below this led to an increased release of tentoxin stored in the cells. The formation of tentoxin by older mycelia was not regulated by acetate, phosphate or glucose, which was not utilized. Precursor amino acids, applied at the start of the culture, slightly activated the synthesis of tentoxin. Older mycelia were inhibited. Substances from the host plant (Brassica chinensis) reduced the de novo synthesis of tentoxin. Enzyme separation studies suggested that biosynthesis of tentoxin involves a multienzyme ( $\geqslant 400 \mathrm{kDa}$ ), which is a polyfunctional protein without subunits. Experiments suggested that the synthetase contains active SH-groups and an integrated activity of methyltransferase. The precursor amino acids are activated by ATP and bound at the enzyme. $\mathrm{N}$-Methylation occurs with the enzyme-bound amino acids or during the elongation of the growing peptide chain. Methionine is the primary donor of the methyl groups, but the immediate methylation reaction needs 5 adenosyl methionine (SAM). The methylation is essential for the continuation of biosynthesis. The elongation proceeds either stepwise from glycine by binding alanine/methylalanine, phenylalanine/methylphenylalanine and leucine or by formation and linkage of two dipeptides glycine-alanine/ methylalanine and phenylalanine/methylphenylalanine-leucine. At the end of this process dihydrotentoxin, the direct precursor of tentoxin, is released from the synthetase probably by cyclization. Independent of this first enzyme, dihydrotentoxin is transformed into tentoxin. This last reaction step is reversible. The rate of transformation of dihydrotentoxin to tentoxin is higher, but in this direction the native turnover is relatively low. The synthesis of tentoxin probably occurs in a manner similar to other well-known cyclic peptides via a 'thiotemplate mechanism'; the highest enzyme activity in vitro occurs between days 9 and 11 of culture at a pH value of 7 .

Keywords: Alternaria alternata, tentoxin biosynthesis, regulation, tentoxin synthetase

\section{INTRODUCTION}

The cyclic tetrapeptide tentoxin [cyclo-(L-leucyl- $N$-methyldehydrophenylalanyl-glycyl- $N$-methylalanyl): Meyer et al., 1971; Koncewicz et al., 1973; Grable et al., 1966;

Abbreviations: DTE, dithioerythritol; SAM, S-adenosyl methionine.
Meyer et al., 1971; Templeton, 1972; Woodhead et al., 1975; Liebermann \& Oertel, 1983] is produced by the deuteromycete Alternaria alternata. It causes chlorosis in many sensitive plants (Durbin \& Uchytil, 1977), probably by inhibiting the development of chloroplasts (Schadler $e t$ al., 1976). Tentoxin also damages the CF1 subunit of the chloroplast-associated ATPase (Steele et al., 1976). The 
last action is probably not directly connected with the chlorotic symptoms. In addition $A$. alternata excretes dihydrotentoxin, the precursor of tentoxin, which contains $N$-methyl-L-phenylalanine, and other related compounds, including a cyclic dipeptide of $\mathrm{N}$-methyl-Lphenylalanine and leucine (Liebermann et al., 1988), non-peptide compounds and conjugates between tentoxin and the non-peptides (B. Liebermann unpublished). These tentoxin-conjugates are produced by the fungus, but they can also be formed to some extent during the isolation of the substances (Liebermann, 1989).

A high level of production of cyclopeptides can be achieved by surface cultivation. The biosynthesis of tentoxin and dihydrotentoxin has so far been investigated only in connection with the optimization of peptide formation under these culture conditions in standing culture flasks. Exogenous phosphate inhibited the synthesis of tentoxin when it was added at the start of cultivation (Brückner et al., 1983; Hänel, 1985). In contrast, acetate stimulated the production of tentoxin (Hänel et al., 1985). The glyoxylate cycle is not activated by acetate but the utilization of glucose is enhanced during early stages of cultivation. Slowly utilized carbon sources do not support the formation of toxin (Oertel, 1983). Based on these results a culture medium for maximum production of tentoxin was developed. Studies of the biosynthesis of tentoxin using the standing culture flasks and selected media (Hänel et al., 1985) were found to be unsuitable for investigations using differentiated mycelia: the culture medium contained tentoxin already released at some time after inoculation and this system was complex and ill-defined. Thus it was not possible to vary one factor selectively. For this reason a new and simple system has been developed which gives detailed conclusions after a short incubation time and with a simple isolation of tentoxin.

Details of the biosynthesis of tentoxin are poorly understood. The investigations by Sheu \& Talburt (1986) and Ramm et al. (1994a) showed that the synthesis of cyclopeptide was catalysed by enzymes. It was of interest to characterize these enzymes and to reveal biochemical details of the biosynthesis. We postulated an enzyme, similar to those for the synthesis of other cyclic peptides, which does not involve ribosomes (Kleinkauf \& von Döhren, 1982). The synthesis probably proceeds without the appearance of free intermediates, because they have not been detected (Liebermann, 1989). Dihydrotentoxin is released first and can be detected in the culture medium (Liebermann \& Ihn, 1988). The dehydrogenation to tentoxin probably is catalysed by a further enzyme that acts independently of the postulated synthetase.

\section{METHODS}

Organism and cultivation. Investigations were carried out with strain i30/10 of A. alternata (Fr.) Keissler isolated in our laboratory from Brassica chinensis. The strain was kept on agar plates at $4{ }^{\circ} \mathrm{C}$. Conidia from the plates were inoculated in a liquid culture medium and cultivated for $48-60 \mathrm{~h}$ on a gyratory shaker at $28{ }^{\circ} \mathrm{C}$. The pellets $(1 \%, \mathrm{w} / \mathrm{v})$ were used as inoculum for surface culture in phosphate-limited medium incubated at $28^{\circ} \mathrm{C}$. Media and further details are given by Hänel (1985) and Hänel et al. (1985).

Treatment of mycelia. After a defined culture time the mycelium was removed and washed in distilled water. Pieces $(1 \times 2 \mathrm{~cm})$ of mycelium $(5 \mathrm{~g})$ were cut from the mycelial mats and incubated without shaking in $20 \mathrm{ml}$ triethanolamine buffer (20 mM with $10 \mathrm{mM} \mathrm{MgCl}, \mathrm{pH} 7 \cdot 5$ ) at $28{ }^{\circ} \mathrm{C}$ for $8 \mathrm{~h}$. To vary $\mathrm{pH}, 200 \mathrm{mM}$ phosphate buffers with constant ion strength and the triethanolamine buffer were used. Tentoxin, newly formed during incubation, was measured by addition of the precursor amino acid [U- $\left.{ }^{14} \mathrm{C}\right]$ leucine $(19 \mathrm{kBq}$; UVVVR Prague; $8888 \mathrm{MBq} \mathrm{mmol}^{-1}$ ) without addition of unlabelled leucine. After incubation the mycelial pieces were washed with $5 \mathrm{ml}$ distilled water. Buffer and wash water were pooled. The experiments were repeated once more with similar results. Representative results are shown in the figures.

Preparation of protoplasts. Protoplasts were prepared with lytic enzymes from Helix pomatia, Trichoderma barzianum and commercial Novozyme (Ramm et al., 1994a) from $5 \mathrm{~g}$ (wet weight) of 9-d-old mycelial mats. Disintegration of the protoplasts was achieved by osmotic shock in distilled water for $15 \mathrm{~min}$. Subsequently, the solution was adjusted to $20 \mathrm{mM}$ triethanolamine $\mathrm{pH} 7.5 \quad\left[10 \mathrm{mM} \quad \mathrm{MgCl}_{2}, \quad 0.25 \mathrm{mM}\right.$ dithioerythritol (DTE)] with concentrated buffer solution to a final volume of $10 \mathrm{ml}$.

Disintegration of frozen mycelia. This was done with a $\mathrm{X}$ Press or a French Press (LKB). The homogenates were suspended in buffer $[50 \mathrm{mM}$ Tris $/ \mathrm{HCl}, \mathrm{pH} 7 \cdot 2,50 \%(\mathrm{w} / \mathrm{v})$ glycerol, $1 \mathrm{mM}$ EDTA, $10 \mathrm{mM}$ DTE] at $0-4{ }^{\circ} \mathrm{C}$. Disintegrated mycelium was then stirred for $15 \mathrm{~min}$ and centrifuged at $500 \mathrm{~g}$. The proteins of the supernatant were precipitated by $80 \%$ $(w / v)$ ammonium sulfate and separated by centrifugation, solubilized in a small amount of buffer $[50 \mathrm{mM}$ Tris $/ \mathrm{HCl}$, $\mathrm{pH} 7 \cdot 2,10 \%$ (w/v) glycerol, $0 \cdot 1 \mathrm{mM}$ EDTA, $2 \mathrm{mM} \mathrm{DTE}]$ and dialysed against the same buffer for $30 \mathrm{~min}$.

Host plant extracts. Extracts of host plant were prepared by homogenization of $15 \mathrm{~g}$ (wet weight) young leaves with $5 \mathrm{ml}$ triethanolamine buffer $(\mathrm{pH} 7 \cdot 5)$ and further filtration. A portion $(20 \mathrm{ml})$ of this extract was used in the buffer system with mycelial pieces instead of the usual buffer.

Isolation of tentoxin/dihydrotentoxin. For experiments in vivo, $10 \mathrm{ml}$ samples of filtered surface culture medium or buffer solution from the incubations with mycelium pieces were passed through $50 \mathrm{mg}$ Porapak Q (Serva). The column $(7 \times 10 \mathrm{~mm}$ ) was washed with $10 \mathrm{ml}$ distilled water and the bound cyclopeptides were eluted with $1 \mathrm{ml}$ methanol (Liebermann et al., 1992). The eluate was separated by TLC on silica gel G (Merck) in ethyl acetate/methanol/water (100:4:1, by vol.). Tentoxin/ dihydrotentoxin was detectable by fluorescence quenching under UV light $\left(R_{F}=0.32\right)$. The spot was separated and the cyclopeptides were eluted. The peptide concentration was measured by UV absorption at $286 \mathrm{~nm}$ (maximum of absorption of tentoxin, Specord Carl Zeiss Jena) and $222 \mathrm{~nm}$ (maximum of absorption of dihydrotentoxin). Newly synthesized toxin was determined by measuring the radioactivity of the tentoxin spot separated from radioactively labelled leucine (LSC, Wallac S 1410, Pharmacia). These steps did not separate tentoxin and dihydrotentoxin. Estimates of relative amounts were possible by comparison of the absorption maxima for the two compounds. Also they could be separated by gel filtration on 
Sephadex G15 (Liebermann \& Ihn, 1988). By this method we detected in vivo no or only very small amounts of dihydrotentoxin and no other products. Thus tentoxin was assumed to be the main component of the radioactively labelled material.

More dihydrotentoxin was formed during experiments in vitro after cell disruption. The two cyclopeptides were measured together. After addition of $50 \mu \mathrm{g}$ non-radioactive tentoxin/ dihydrotentoxin for better extraction efficiency the proteins precipitated by TCA were separated and the incubation mixture was passed through Porapak Q. After separation by TLC as before, the spot was eluted and tentoxin was rechromatographed in $n$-butanol/acetic acid/water (12:3:5, by vol.). The distribution of radioactivity on the second chromatogram was measured in a dioxan scintillation fluid.

The preparation of precursors of the cyclic peptides separated from the enzyme in vitro was carried out in an analogous way. The linear tetrapeptide chain was separated with the first solvent system on the origin of the chromatogram. A repeated separation in $n$-butanol/acetic acid/water (63:10:27, by vol.) liberated this metabolite from traces of free amino acids. Identification was done by the analysis of hydrolysate (dansylation) and by comparison with a linear tetrapeptide prepared from tentoxin (Koncewicz et al., 1973).

For investigation of the conversion of tentoxin into dihydrotentoxin both substances were separated by gel filtration on Sephadex G 15 (Liebermann \& Ihn, 1988).

Isolation of enzyme-bound intermediates. Crude protein extract $(1 \mathrm{ml})$ from protoplasts $\left(20 \mu \mathrm{g} \mathrm{ml}\right.$ protein $\left.{ }^{-1}\right)$ was incubated with $50 \mu \mathrm{l} \mathrm{ATP}-\operatorname{mix}, 20 \mu \mathrm{l}\left[\mathrm{U}_{-}^{14} \mathrm{C}\right]$ amino acids (each $1 \mathrm{nM}$ with $\left.1.6 \times 10^{4} \mathrm{~Bq}\right), 20 \mu \mathrm{l} \operatorname{SAM}(0.7 \mathrm{mM})$ for 0,5 and $15 \mathrm{~min}$ at $28^{\circ} \mathrm{C}$. The reaction was terminated by TCA and the protein was separated on membrane filters. Unbound amino acids were washed out with $14 \%(\mathrm{w} / \mathrm{v})$ TCA and distilled water. The protein was dissolved in $1 \mathrm{ml}$ water and the solution was adjusted to $\mathrm{pH} 9$ with $1 \mathrm{M} \mathrm{NaOH}$. The enzymeintermediate complexes labile in alkali were hydrolysed by heating at $100{ }^{\circ} \mathrm{C}$ for $5 \mathrm{~min}$. After neutralization with TCA $3 \mathrm{ml}$ methanol was added and the filter and protein precipitate were separated by centrifugation. The intermediates remaining in the supernatant were separated by TLC in $n$-butanol/acetic acid/water (63:10:27, by vol.). The resulting three radioactively labelled peaks were eluted and separated in phenol/ water $\left[72: 25(\mathrm{v} / \mathrm{v}) ; 3 \% \mathrm{NH}_{3}\right.$-atmosphere $]$ after hydrolysis $(6 \mathrm{M}$ $\left.\mathrm{HCl}, 24 \mathrm{~h}, 110^{\circ} \mathrm{C}\right)$.

[U- ${ }^{14}$ C]Amino acids. These were from UVVVR Prague (specific activities: alanine $4440 \mathrm{MBq} \mathrm{mmol}^{-1}$; glycine $2960 \mathrm{MBq} \mathrm{mmol}^{-1}$; leucine $8888 \mathrm{MBq} \mathrm{mmol}^{-1}$; phenylalanine $13320 \mathrm{MBq} \mathrm{mmol}^{-1}$ ). Also used were ${ }^{3} \mathrm{H}-\mathrm{SAM}$ and ${ }^{32} \mathrm{P}$-pyrophosphate $\left(\mathrm{PP}_{\mathrm{i}}\right)$ (Amersham).

Enrichment of tentoxin synthetase. Protein crude extracts were treated by the following steps (all at $4{ }^{\circ} \mathrm{C}$ ): (a) gel filtration on Ultrogel AcA 34 (Serva) and Sephadex G-200 (Pharmacia) [buffer $50 \mathrm{mM}$ Tris $/ \mathrm{HCl}, \mathrm{pH} 7 \cdot 2$ with $10 \%$ (v/v) glycerol, $0.1 \mathrm{mM}$ EDTA, $2 \mathrm{mM}$ DTE; $2.6 \times 40 \mathrm{~cm}$ column, $3 \mathrm{mg}$ protein, $4.5 \mathrm{ml}$ fractions; $5 \times 100 \mathrm{~cm}$ column, $25 \mathrm{mg}$ protein, $13 \mathrm{ml}$ fractions, respectively], absorbance at $280 \mathrm{~nm}$ was measured; (b) three-phase extraction of $6.7 \%$ disintegrated cells with $11 \%$ PEG 8000 (Serva), 5\% Dextran 251 (Sigma), 8\% Ficoll (Pharmacia) all $\mathrm{w} / \mathrm{v}$ in buffer $[50 \mathrm{mM}$ Tris/ $\mathrm{HCl}, \mathrm{pH} 7.2$ with $10 \%(\mathrm{v} / \mathrm{v})$ glycerol, $0.1 \mathrm{mM}$ EDTA, $2 \mathrm{mM}$ DTE] by stirring for $30 \mathrm{~min}$ at $20^{\circ} \mathrm{C}$ followed by centrifugation at $10000 \mathrm{~g}$ for
15 min and separation of the phases; (c) ultracentrifugation of protein in a density gradient of $0-30 \%(\mathrm{w} / \mathrm{v})$ sucrose for $24 \mathrm{~h}$ at $100000 \mathrm{~g}$ followed by collection of $1 \mathrm{ml}$ fractions from the gradient starting at the bottom of the centrifugation tube.

The active fractions were subjected to further purification as follows: ion exchange chromatography on QAE-Sepharose and DEAE-Cellulose (buffer $50 \mathrm{mM}$ Tris $/ \mathrm{HCl}$, pH $7 \cdot 2$ with $10 \%$ (v/v) glycerol, $0 \cdot 1 \mathrm{mM}$ EDTA, $2 \mathrm{mM}$ DTE, $2 \times 15 \mathrm{~cm}$ column, $4.5 \mathrm{ml}$ fractions). Elution was with a linear $0-1 \mathrm{M} \mathrm{NaCl}$ concentration gradient. Hydrophobic interaction chromatography and affinity chromatography were carried out on $3 \mathrm{ml}$ Phenylsepharose CL $4 \mathrm{~B}$ (Pharmacia), and the protein was eluted by steps, each of $4 \mathrm{ml}$, of $0-1 \mathrm{M} \mathrm{NaCl}$ followed by $50-100 \%$ (v/v) ethyleneglycol.

Measurement of tentoxin synthetase activity. (1) To detect activation of amino acids. (a) ATP/ $\mathrm{PP}_{\mathrm{i}}$-exchange. The standard incubation mixture contained $100-150 \mu$ l enzyme solution, $5 \mu \mathrm{l}$ of the respective amino acid (alanine, glycine, leucine, phenylalanine, $5 \mathrm{mM}$ each), $50 \mu \mathrm{l}$ ATP $/{ }^{32} \mathrm{P}-\mathrm{PP}_{\mathrm{i}}$-mix (ATP, PP, $1.2 \mathrm{mM}$ each). The control tube contained buffer instead of amino acid. After $45-60 \mathrm{~min}$ incubation at $28^{\circ} \mathrm{C}$ the reaction was terminated by addition of $0.5 \mathrm{ml}$ of a solution of perchloric acid and charcoal $\left[42 \cdot 8 \mathrm{~g} \mathrm{Na}_{4} \mathrm{P}_{2} \mathrm{O}_{7} .10 \mathrm{H}_{2} \mathrm{O}, 43 \cdot 2 \mathrm{ml} \mathrm{HClO}_{4} \mathrm{l}^{-1}\right.$ with $1.2 \%(\mathrm{w} / \mathrm{v})$ Norit $\mathrm{A}]$ and the radioactivity bound to the charcoal was separated on paper filters (Schleicher \& Schuell, $0.8 \mu \mathrm{m}$; Gevers et al., 1969). After washing and drying the filters $\left(15 \mathrm{~min}\right.$ at $\left.110^{\circ} \mathrm{C}\right)$ the radioactivity was measured in a liquid scintillation counter. (b) The binding of precursor amino acids to tentoxin synthetase. The standard incubation mixture contained $100-150 \mu \mathrm{l}$ enzyme solution, $200 \mu \mathrm{l}$ [U- ${ }^{14} \mathrm{C}$ ]amino acid (alanine, glycine, leucine, phenylalanine without addition of non-radioactive amino acids), $20 \mu \mathrm{l}$ ATP-mix (ATP $0.5 \mathrm{mM}$ ). The control tube contained no ATP. The reaction $\left(1 \mathrm{~h}, 28^{\circ} \mathrm{C}\right)$ was terminated by the addition of TCA. After $30 \mathrm{~min}$ at $0^{\circ} \mathrm{C}$ the precipitated protein was separated, washed on membrane filters (Sartorius, cellulose acetate, $0.45 \mu \mathrm{m}$ ) and the bound radioactivity was measured.

(2) To measure the complete biosynthesis of tentoxin and dihydrotentoxin. The standard incubation mixture contained $1 \mathrm{ml}$ enzyme solution, $150 \mu \mathrm{l}$ ATP-mix (ATP, $0 \cdot 35 \mathrm{mM}$ ), $30 \mu \mathrm{l}$ SAM ( $1 \mathrm{mM}$ ), $20 \mu \mathrm{l}$ of all amino acids (each $1 \mathrm{nM}$, only alanine, glycine, leucine were radioactively labelled). Incubation was carried out for 2.5 or $4 \mathrm{~h}$ at $28^{\circ} \mathrm{C}$ and was terminated by the addition of $110 \mu 172 \%(\mathrm{w} / \mathrm{v})$ TCA. The ATP-mix contained $50 \mathrm{mM}$ Tris/ $\mathrm{HCl}, \mathrm{pH} 7 \cdot 2,5 \mathrm{mM} \mathrm{ATP}, 50 \mathrm{mM} \mathrm{MgCl}_{2}, 5 \mathrm{mM}$ EDTA and $5 \mathrm{mM}$ DTE.

SAM-labelling. To $100 \mathrm{ml}$ of crude enzyme $5 \mu \mathrm{l}(5 \mu \mathrm{Ci} ; 185 \mathrm{kBq})$ ${ }^{3} \mathrm{H}$-SAM was added and the mixture was exposed to UV-light $(260 \mathrm{~nm}, 10 \mathrm{~cm}$ distance) for $10 \mathrm{~min}$. The radioactively labelled SAM become bound to the catalytic centre of the methyltransferase activity ( $H$. von Döhren, personal communication).

Analytical methods. PAGE was carried out as described by Laemmli (1970) with $7 \cdot 5 \%$ or, in most cases, $5 \%$ (w/v) gels. Gradient gels contained 3-15\% (w/v) acrylamide. Protein staining was carried out with Coomassie brilliant blue R-250 and by silver staining (protein silver staining kit, National Diagnostics). Western blot analysis and ELISA were carried out each with lamb anti-tyrocidine synthetase 1 antibodies (given by H. von Döhren, Technical University, Berlin) and anti-lamb IgG-phosphatase conjugate. Protein determination was done using the method of Bradford (1976). Determination of chloride ions was carried out by the method of Mohr (1958). Detection 


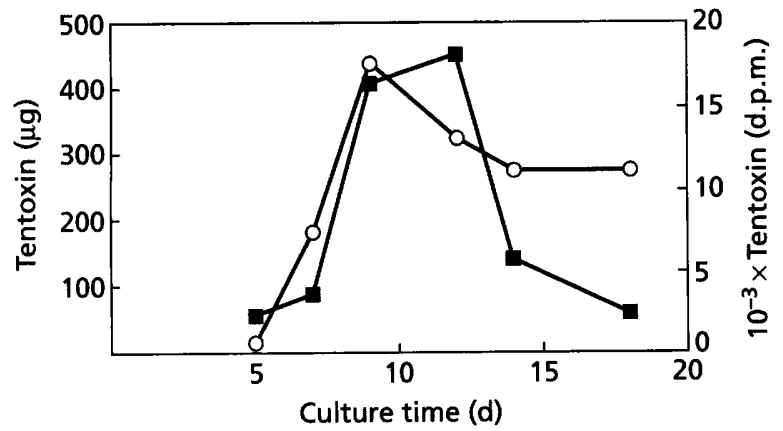

Fig. 1. Tentoxin formation by Alternaria alternata. $O$, Total concentration of tentoxin in $\mu \mathrm{g}$ per incubation assay (each in $20 \mathrm{ml}$ buffer); newly formed tentoxin expressed as radioactivity per incubation assay.

of amino acids on chromatograms after TLC was done by (a) spraying with $0.3 \%$ ninhydrin in $n$-butanol and $3 \%$ acetic acid, or (b) spraying with solution described by Russell (1960), each then being heated at $110^{\circ} \mathrm{C}$. Dansylation was by the method of Neuhoff (1973).

\section{RESULTS AND DISCUSSION}

\section{Physiology of tentoxin biosynthesis - in vivo experiments}

Tentoxin and dihydrotentoxin are very similar in both their structure and properties. For this reason it was not possible to separate them by measuring the de novo synthesis from $\left[\mathrm{U}^{14} \mathrm{C}\right]$ leucine. However, it is not important to separate the peptides to get information about the biosynthesis of tentoxin because dihydrotentoxin is the direct precursor of tentoxin. On the other hand, the measurement of total tentoxin at $286 \mathrm{~nm}$ is specific, because dihydrotentoxin does not absorb at this wavelength. Moreover, in the buffer system with washed pieces of mycelium only very small amounts of dihydrotentoxin were formed in contrast to the surface culture medium in standing flasks.

Mycelium from Alternaria alternata produced tentoxin by day 5 after inoculation (Fig. 1). Synthesis quickly increased after day 5 and reached a maximum between days 9 and 12 of culture. Between days 14 and 18 the synthesis declined to the level of day 5 . Dihydrotentoxin was not detected in the buffer during this experiment.

It was possible to distinguish between newly formed tentoxin/dihydrotentoxin and the tentoxin released. By measuring the absorbance at $286 \mathrm{~nm}$ and $222 \mathrm{~nm}$ we could determine the sum of both. By incorporation of [U$\left.{ }^{14} \mathrm{C}\right]$ leucine the de novo synthesis of cyclopeptides could be detected selectively. While $\mathrm{pH}<6$ and $>8$ led to a higher release of accumulated tentoxin, $\mathrm{pH}$ 6-8 stimulated de novo synthesis. Therefore culture at $\mathrm{pH} 7$ and increasing the $\mathrm{pH}$ at the end of the cultivation enhanced the tentoxin yield.

A. alternata produces only traces of tentoxin in submerged cultures (Hänel, 1985; Liebermann, 1989). Under sub- merged conditions $\mathrm{NH}_{3}$ was formed earlier and in greater amounts than in surface cultivation. Therefore the $\mathrm{pH}$ increased more quickly to a suboptimal level. This might be one reason for the minimal yield of tentoxin in submerged culture.

During the high production of tentoxin, glucose was not taken up within $10 \mathrm{~h}$ and was not utilized in either primary or secondary metabolism. The toxin formation rate was not changed by addition of glucose (Fig. 2). In contrast, glucose did not regulate the biosynthesis as an external effector. Evidence of the function of glucose was given by Oertel (1983). When glucose was added at the start of the cultivation it was readily utilized compared to slowly usable carbon sources and led to an optimal peptide synthesis. Carbon catabolite repression was not observed, and glucose did not inhibit the expression of the tentoxin synthesizing enzymes, in contrast to the situation with $\beta$-lactam antibiotics (Martin \& Demain, 1980; Zhang et al., 1989). Tentoxin is produced at a glucose concentration of $20 \mathrm{~g} \mathrm{l}^{-1}$ (Hänel, 1985).

Hänel et al. (1985) and Liebermann (1989) described the positive regulatory effect of acetate on the toxin synthesis at the start of cultivation. Acetate probably acts as an inducer for the expression of synthesizing enzymes. Metabolic effects of acetate on differentiated mycelia were not detected in our work. Addition of acetate to older mycelia did not activate the uptake or the utilization of glucose in contrast to young mycelia. Acetate together with glucose led to steady formation of tentoxin in the mycelium-section system after 6-8 hours (Fig. 2). These results with the mycelial pieces on buffer agree with data from surface cultures (Liebermann et al., 1991).

Our results suggest a channelling by the amino acid pools of the fungal cells. Therefore it was possible to supply only traces of $\left[\mathrm{U}_{-}{ }^{14} \mathrm{C}\right]$ leucine into the pool of leucine leading to a high incorporation rate into tentoxin.

Phosphate inhibited tentoxin synthesis when added at the start of cultivation (Brückner et al., 1983; Edel et al., 1985; Hänel, 1985). In this study, de novo biosynthesis of tentoxin

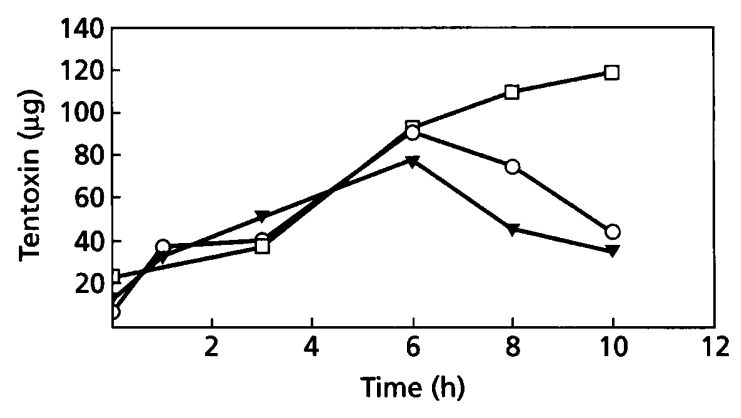

Fig. 2. Production of tentoxin by mycelial sections. $O$, Under standard conditions without glucose $(0-10 \%$ of cyclopeptides as dihydrotentoxin); $\nabla$, after added glucose $\left(5 \mathrm{gl}^{-1}\right)(0-30 \%$ of cyclopeptides as dihydrotentoxin); $\square$, after addition of glucose and acetate $\left(3.7 \mathrm{gl}^{-1}\right)$ (no cyclopeptide as dihydrotentoxin). 
Table 1. Regulation of the synthesis of tentoxin by precursor amino acids

Amino acids were added at a concentration of $4 \mathrm{~g} \mathrm{l}^{-1}$ at the start of surface culture in liquid culture medium or at $5 \mathrm{~g} \mathrm{l}^{-1}$ to mycelium at day 10 of cultivation. No dihydrotentoxin was included. Values are expressed as a percentage of the control without amino acids and are means of two experiments.

\begin{tabular}{|lrc|}
\hline Amino acid & \multicolumn{2}{c|}{ Tentoxin } \\
\cline { 2 - 3 } & $\begin{array}{rr}\text { Start of } \\
\text { culture }\end{array}$ & $\begin{array}{c}\text { Day } \\
\mathbf{1 0}\end{array}$ \\
\hline Alanine & 105 & 95 \\
Glycine & 85 & 70 \\
Leucine & 130 & 55 \\
Phenylalanine & 100 & 53 \\
Methionine & 3 & 70 \\
All amino acids together & 15 & 30 \\
\hline
\end{tabular}

by differentiated, toxin-forming mycelium was not affected by adding phosphate up to $200 \mathrm{mM}$. Mycelial pieces at day 10 of culture in standing flasks produced $230 \mu \mathrm{g}$ tentoxin on $20 \mathrm{ml}$ triethanolamine buffer corresponding to $200 \mu \mathrm{g}$ tentoxin on $20 \mathrm{ml}$ phosphate buffer.

Addition of precursors often leads to an increased formation of products. The production of cyclosporin was increased after addition of valine and leucine (Lee \& Agathos, 1989). Thus it was possible that provision of precursor amino acids might influence the synthesis of tentoxin. Methionine as a donor of methyl groups for the methylation of alanine and phenylalanine was also thought to be necessary for a high yield of tentoxin (Liebermann \& Ramm, 1991).

Amino acids added at the start of the cultivation or after $10 \mathrm{~d}$ to the surface culture in standing flasks did not increase the yield of toxin. Only alanine and leucine had a small positive influence (Table 1). Addition of methionine probably led to a channelling of the formation of secondary product to other compounds and the synthesis of tentoxin was inhibited. The changed spectrum of products points to competitive reactions (Fig. 3). Methionine might regulate the alternariol-o-methyltransferase which forms alternariol monomethyl ether. Alternariol and alternariol monomethyl ether synthesis are inhibited by $12 \mathrm{mM} \mathrm{NaNO}$ (Orvehed et al., 1988). Because the medium used for tentoxin formation contains $70 \mathrm{mM}$ $\mathrm{NaNO}_{3}$ this effect was exploited for toxin synthesis. Methionine might abolish this influence by a strong activation or induction of this enzymic step towards alternariol monomethyl ether. Thus, the formation of alternariol monomethyl ether increased and the synthesis of tentoxin declined.

Extracts of the host plant Brassica chinensis inhibited the synthesis of tentoxin in the mycelium-buffer system.

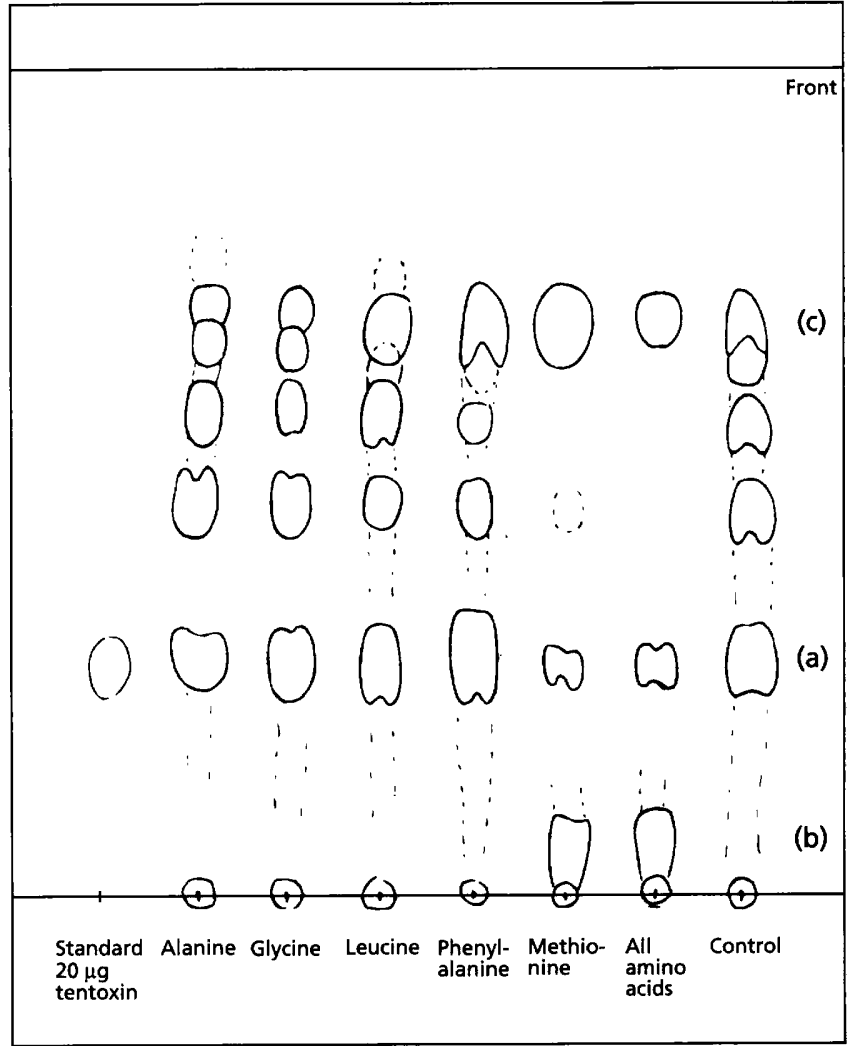

Fig. 3. Effect of addition of amino acids on spectrum of products synthesized, as shown by separation of TLC in ethylacetate/methanol/water $(100: 4: 1$, by vol). (a) Tentoxin/dihydrotentoxin; (b), (c) alternariol and alternariol monomethyl ether-like products, respectively.

Mycelium incubated with plant extract formed only $37 \%$ tentoxin compared to the control on buffer. The production of secondary compounds was displaced to other substances perhaps similar to alternariol and alternariol monomethyl ether.

\section{Enzymic biosynthesis of tentoxin - in vitro investigations}

The multienzyme responsible for tentoxin biosynthesis is likely to be a protein with molecular mass $\geqslant 200-250 \mathrm{kDa}$ (Kleinkauf \& von Döhren, 1982). The search for such proteins showed that the crude protein extract contained large proteins, which ran as single bands in the polyacrylamide gel under reducing conditions (Fig. 4a, left). There were also proteins which showed cross reaction with anti-tyrocidine synthetase antibodies [tyrocidine synthetase also has a binding locus for ATP and for phenylalanine (Roskoski et al., 1970) (Fig. 4a, right)]. The SAM-labelling in such large proteins [high-molecularmass proteins (arrows in Fig. 4b, lanes 3 and 4 correlated with radioactive labelling on lane 7)] suggested integration of methyltransferase in the multienzyme as in the case of actinomycin synthetase (Keller \& Kleinkauf, 1977). Results correlating tentoxin synthetase activity and 

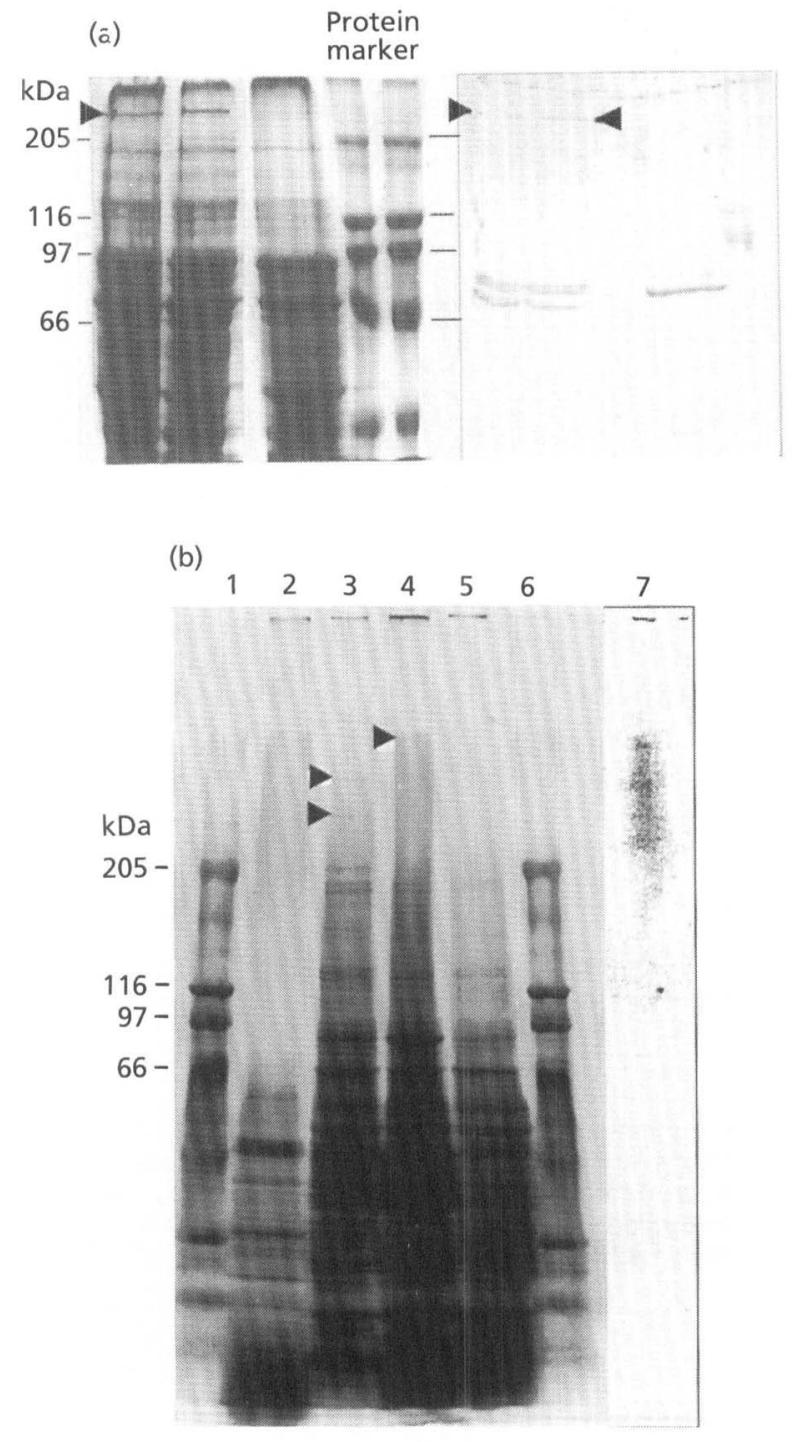

Fig. 4. High-molecular-mass proteins of tentoxin-producer $\boldsymbol{A}$. alternata strain i30/10. (a) Coomassie blue-stained $5 \%$ polyacrylamide gel (left); Western blot (right). (b) GradientPAGE with 3-15\% acrylamide with crude protein from days 8 (lane 2); 11 (lane 3); 12 (lane 4); 14 (lane 5) of mycelial culture, silver-stained and autoradiographed for 3 weeks after SAMlabelling. Lanes 1 and 6, protein markers; lane 7, autoradiograph on Kodak X-Omat S.

possible SAM-labelling during enzyme entichment experiments support this hypothesis.

The highest content of proteins above $200 \mathrm{kDa}$ was detected in mycelia from the day 11 /day 12 of culture (Fig. 4b, lanes 3 and 4). It correlated with the highest biosynthetic ability of mycelium. The danger of enzyme degradation by proteases is relatively low during this time, because there was low activity of proteases in the crude protein extract as assayed with casein agar (results not shown).

Investigations in enrichment of tentoxin synthetase gave

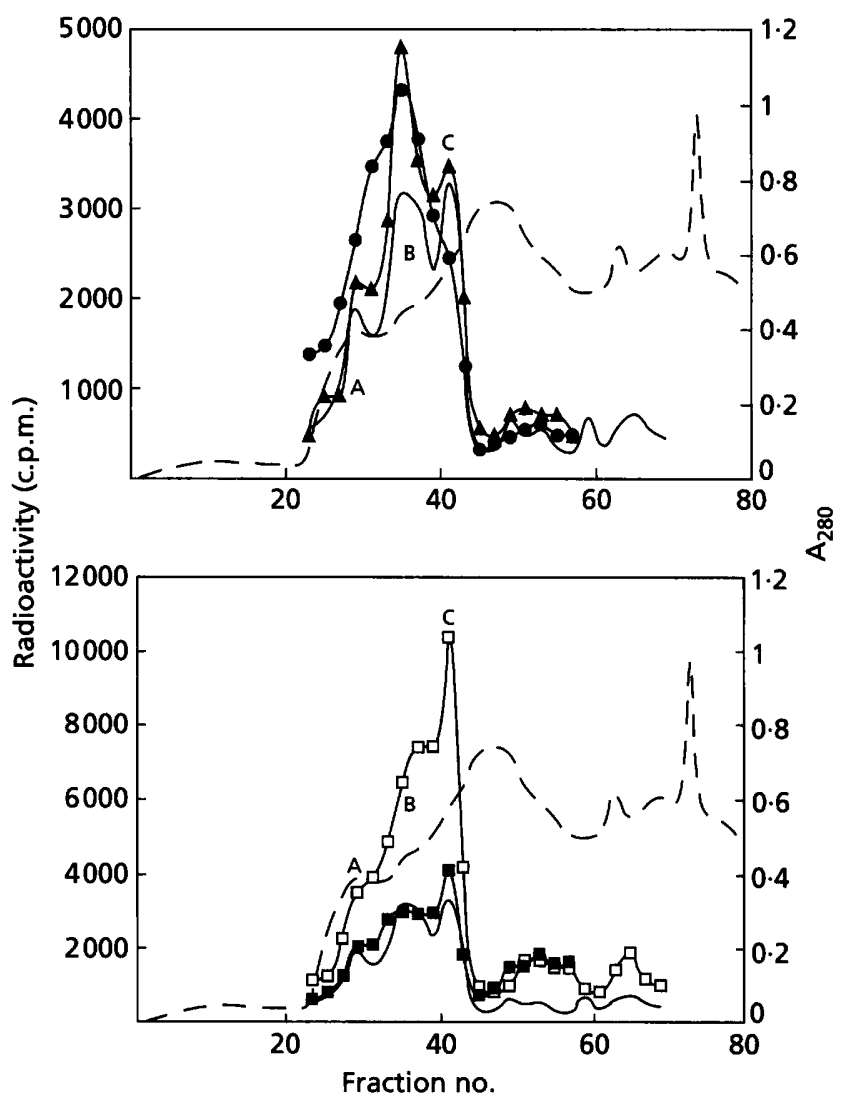

Fig. 5. Activation of amino acids after precipitation with ammonium sulphate and separation of $25-30 \mathrm{mg}$ protein on Ultrogel ACA 34. - Control without amino acid, showing unspecific ATP-PP ${ }_{i}$ exchange; $\Delta$, alanine; 0 , glycine; $\square$, leucine; $\mathbf{a}$, phenylalanine; ---, $A_{280}$.

proteins which activated all four amino acids and formed tentoxin/dihydrotentoxin in part. The active proteins ran in the void volume during gel filtration on Ultrogel AcA 34 (Fig. 5) and showed a little cross reaction with antityrocidine synthetase 1 antibodies in the ELISA. Fractions containing tentoxin synthetase eluted from DEAE-cellulose at $0 \cdot 2-0 \cdot 3 \mathrm{M} \mathrm{NaCl}$ (Fig. 6). During three-phase extraction the enzyme was concentrated in the Ficoll phase. The enzyme eluted at $0.4 \mathrm{M} \mathrm{NaCl}$ from Phenylsepharose CL-4B.

Separation by ultracentrifugation in a sucrose density gradient led to active fractions in the sediment but also in a region of less density, correlating with the report that some tentoxin synthetase is localized in the membrane (Ramm et al., 1994b). All enzyme fractions active by synthesis contained a protein of about $400 \mathrm{kDa}$ shown in PAGE under reducing conditions (markers: Merck VIII, ferritin, catalase).

The activation of the precursor amino acids, the first step of biosynthesis, was dependent on ATP; the reaction products $\mathrm{PP}_{\mathrm{i}}$ and AMP were released. These results are similar to those from other multifunctional enzymes which synthesize cyclic peptides or peptide derivatives. 


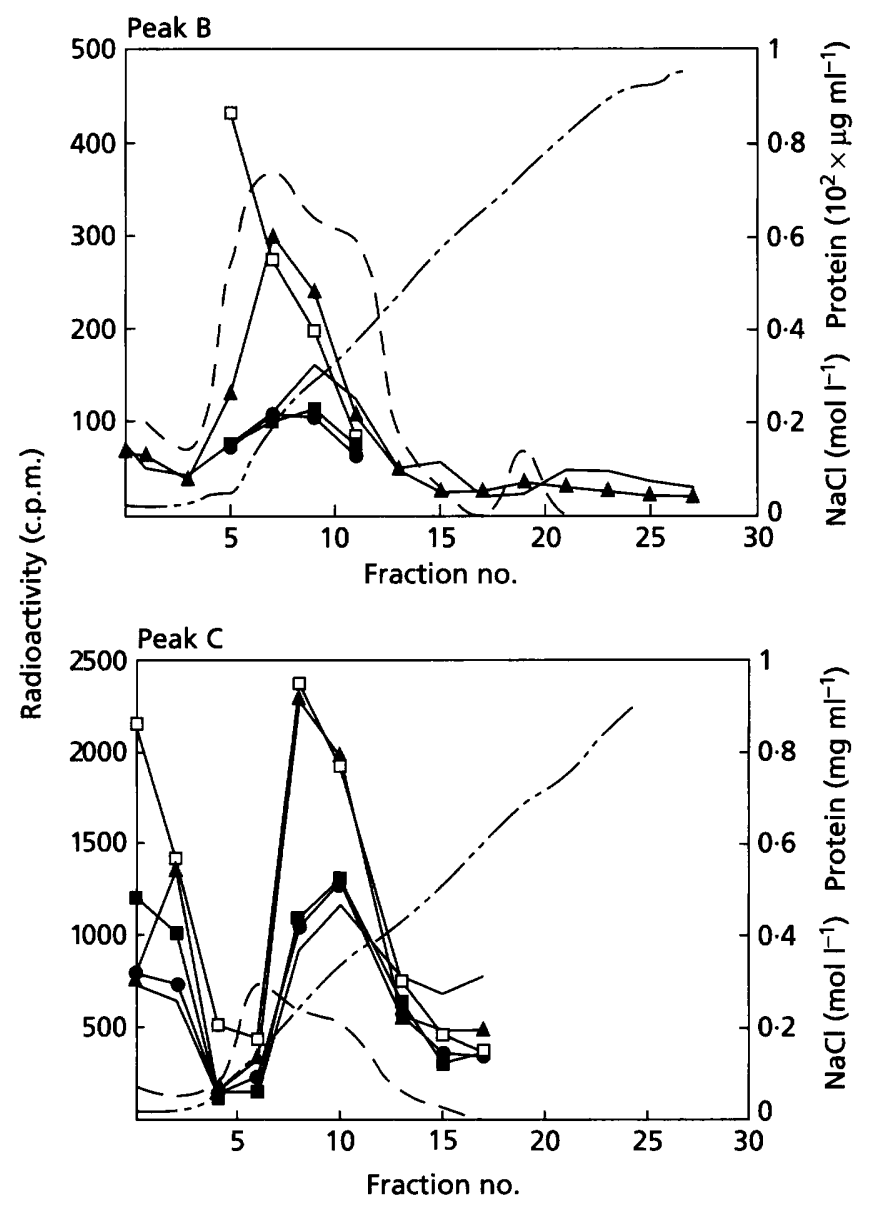

Fig. 6. Activation of amino acids after separation by ion exchange chromatography on DEAE-cellulose of peaks $B$ and $C$ from the gel filtration shown in Fig. 5. - Control; $\mathbf{A}$, alanine; 0 , glycine; $\square$, leucine; $\square$, phenylalanine; $-\cdots-, \mathrm{NaCl}$ gradient; ---, protein.
ADP was not used and AMP inhibited the reaction (Table 2). Similar properties were found by Gevers et al. (1968) and Roskoski et al. (1970) during the investigation of gramicidin synthetase.

Experiments suggested that the tentoxin synthetase contains active SH-groups. The enzyme needed the protection of SH-groups by DTT or DTE. A short time separation of the thiolprotector from the enzyme (compare control with $3 \mathrm{mM}$ DTT and probe with $3 \mathrm{mM}$ DTT in Table 3 ) led to a loss of enzyme activity. The optimum was $1 \mathrm{mM}$ DTT; above this concentration the thiolprotector started to competitively inhibit the enzyme (Table 3). Similar results were found with ACVsynthetase (van Liempt, 1988). These effects could be seen both in activation of amino acids and in translocation for peptide elongation, so that $\mathrm{SH}$-groups are important in both processes. Thioester binding of the amino acids by the enzyme was suggested by the finding that activated and protein-bound amino acid (leucine) could be separated by gentle alkaline hydrolysis ( $\mathrm{pH}$ 9) up to $60 \%$ (compare Gevers et al., 1969).

Isolation and identification of enzyme-bound intermediates gave evidence for the process of biosynthesis. Three main spots, detected by measuring radioactivity of intermediate products, could be obtained for 0,5 and $15 \mathrm{~min}$ of incubation after the first selection step. At $0 \mathrm{~min}$ spot 1 was the major compound. At $5 \mathrm{~min}$ spots 2 and 3 were the major compounds; after 15 minutes spot 3 was somewhat decreased. Analysis of the compounds 1-3 ( $5 \mathrm{~min}$ and $15 \mathrm{~min}$ incubation time) was done by hydrolysis and separation of the radioactively-labelled amino acids. Hydrolysate of compound 1 contained nearly all amino acids (methylated and unmethylated) in the same total radioactivity. The compound from spot 2 contained highly labelled glycine and alanine/methylalanine and less

Table 2. Dependence of tentoxin synthesis on ATP

Added radioactivity $2 \cdot 4 \times 10^{4} \mathrm{~Bq}$, incubation $2.5 \mathrm{~h}$. The radioactivity shown (d.p.m.) is after subtraction of reference.

\begin{tabular}{|c|c|c|c|c|c|}
\hline \multirow{2}{*}{$\begin{array}{c}\text { ATP } \\
(\mathbf{m M})\end{array}$} & \multirow{2}{*}{$\begin{array}{c}\mathrm{ADP} \\
(\mathrm{mM})\end{array}$} & \multirow{2}{*}{$\begin{array}{l}\text { AMP } \\
(\mathrm{mM})\end{array}$} & \multicolumn{3}{|c|}{ Products (d.p.m.) } \\
\hline & & & $\begin{array}{c}\text { Tentoxin/ } \\
\text { dihydrotentoxin }\end{array}$ & $\begin{array}{c}\text { Linear } \\
\text { tetrapeptide, } \\
\text { precursor of } \\
\text { cyclopeptides }\end{array}$ & Total \\
\hline 0 & 0 & 0 & 0 & 0 & 0 \\
\hline 0.5 & 0 & 0 & 1320 & 2440 & 2065 \\
\hline 1 & 0 & 0 & 2881 & 2821 & 4287 \\
\hline $3 \cdot 1$ & 0 & 0 & 4201 & 5261 & 6352 \\
\hline 0 & $3 \cdot 1$ & 0 & 412 & ND & ND \\
\hline $3 \cdot 1$ & 0 & $3 \cdot 1$ & 1510 & ND & ND \\
\hline
\end{tabular}

ND, Not determined. 
Table 3. Dependence of tentoxin synthesis on thiolprotectors, correlation between enzyme activity and dithiothreitol (DTT) concentration

Radioactivity added was $3.2 \times 10^{4} \mathrm{~Bq}$ in each case, incubation $2 \mathrm{~h}$, references with denaturated protein were subtracted. With the exception of the control, DTT was separated by gel filtration before the experiment was started.

\begin{tabular}{|lrc|}
\hline $\begin{array}{l}\text { DTT concn } \\
(\mathbf{m M})\end{array}$ & $\begin{array}{c}\text { Tentoxin } \\
\text { (d.p.m.) }\end{array}$ & $\begin{array}{c}\text { Activated } \\
\text { amino } \\
\text { acids } \\
\text { (d.p.m.) }\end{array}$ \\
\hline 0 & 0 & 360 \\
$0 \cdot 3$ & 1250 & 2580 \\
1 & 1820 & 1230 \\
3 & 824 & 3690 \\
3 (control) & 2370 & 16200 \\
\hline
\end{tabular}

radioactivity in phenylalanine and only traces of leucine. In the hydrolysate of compound 3 leucine and phenylalanine/methylphenylalanine were labelled. Radioactivity in glycine and alanine was low.

The $\left[\mathrm{U}-{ }^{14} \mathrm{C}\right]$ amino acids used had the same absolute radioactivities but not the same specific radioactivities. For this reason we expressed the detected radioactivity in the amino acids relative to the number of carbon atoms and the specific radioactivity of each amino acid to compare their molar relationship (Table 4). The first compound contained all four amino acids including the methyl amino acids and was probably the linear tetrapeptide. The high content of alanine and glycine appeared to be contaminations with traces of free amino acids which had the same $R_{F}$ value as spot 1 under these separation conditions. The compound from spot 2 contained only alanine/methylalanine and glycine and so was a dipeptide. Spot 3 contained mainly leucine and phenylalanine/methylphenylalanine but also traces of alanine and glycine. Because there was no contamination of spots 2 and 3 by free amino acids, two interpretations are possible for compound 3: either it was a dipeptide of the first two amino acids or a tetrapeptide (perhaps cyclic?). The biosynthesis of tentoxin via dihydrotentoxin therefore starts either with glycine and alanine/ methylalanine and proceeds to leucine and phenylalanine/ methylphenylalanine in a linear process similar to the synthesis of gramicidin (Kleinkauf \& von Döhren, 1982) or with the formation and linking of two dipeptides of glycine-alanine/methylalanine and phenylalanine/ methylphenylalanine-leucine similar to the synthesis of actinomycin (Keller, 1987).

Methylation of the enzyme-bound amino acid intermediates occurred during their elongation, because both methylated and unmethylated forms were found as intermediates of the biosynthesis. This corresponds to the biosynthesis of enniatin (Zocher et al., 1976). Synthesis of cyclosporin A differs by terminal methylation after completion of peptide synthesis with unmethylated amino acids and cyclization (Zocher et al., 1986). The immediate methylation of alanine and phenylalanine occurs by SAM and is essential for continuing the biosynthesis. Without methylation the biosynthesis of tentoxin/dihydrotentoxin was strongly inhibited, as in the biosynthesis of enniatin, and no cyclopeptide could be detected. Free unmethylated intermediates could not be detected in culture medium or incubation solutions. The primary donor of the methyl groups is methionine (Liebermann \& Ramm, 1991).

The optimum $\mathrm{pH}$ value in vitro lies between $\mathrm{pH} 6$ and 7 . Biosynthetic activity decreases slowly below $\mathrm{pH} 6$ but rapidly above $\mathrm{pH}$ 7. This corresponds to the results of in vivo experiments.

Tentoxin synthetase activity in crude protein extract of protoplasts in Tris buffer $(50 \mathrm{mM}, \mathrm{pH} \mathrm{7 \cdot 2)}$ could be

Table 4. Ratios of radioactivity of single amino acids and composition of the intermediates of tentoxin synthesis after hydrolysis

The ratios shown are glycine: alanine/methylalanine:leucine:phenylalanine/methylphenylalanine.

\begin{tabular}{|c|c|c|c|c|}
\hline \multirow[t]{2}{*}{ Probe } & \multirow{2}{*}{$\begin{array}{c}\text { Incubation } \\
\text { time } \\
\text { (min) }\end{array}$} & \multicolumn{3}{|c|}{ Amino acid ratio } \\
\hline & & Measured & $\begin{array}{l}\text { Relative to } C \\
\text { and specific } \\
\text { radioactivity }\end{array}$ & Molar ratio \\
\hline \multirow[t]{2}{*}{ Intermediate 1} & 5 & $1: 1 \cdot 3: 0 \cdot 9: 1 \cdot 2$ & $1: 0 \cdot 4: 0 \cdot 15: 0 \cdot 13$ & \\
\hline & 15 & $1: 1 \cdot 2: 0 \cdot 2: 0 \cdot 4$ & $1: 0 \cdot 4: 0 \cdot 03: 0 \cdot 04$ & $10: 5: 1: 1$ \\
\hline \multirow[t]{2}{*}{ Intermediate 2} & 5 & $1: 1 \cdot 5: 0 \cdot 09: 0 \cdot 3$ & $1: 0 \cdot 5: 0 \cdot 01: 0 \cdot 04$ & \\
\hline & 15 & $1: 1 \cdot 7: 0 \cdot 1: 0 \cdot 3$ & $1: 0 \cdot 6: 0 \cdot 01: 0 \cdot 03$ & $100: 50: 1: 3$ \\
\hline \multirow[t]{2}{*}{ Intermediate 3} & 5 & $1: 6 \cdot 5: 44: 48$ & $1: 2: 7: 5 \cdot 5$ & \\
\hline & 15 & $1: 3: 16: 21$ & $1: 1: 2 \cdot 6: 2 \cdot 4$ & $1: 1: 5: 5$ \\
\hline
\end{tabular}


preserved for 3-4 weeks at $-20{ }^{\circ} \mathrm{C}$ without much loss of activity, but after that the activity decreased quickly.

The identification of the tentoxin/dihydrotentoxin fractions formed in vitro showed that dihydrotentoxin was the major product under these conditions. Also the cyclopeptides were partly connected with nonpeptides (Liebermann, 1989) to form 'tentoxin conjugates'. This reaction of the tentoxin probably resulted from loss of compartmentation during preparation. These products were characterized by extensive separations by TLC in several solvent systems (compared with standard substances). The compounds were also characterized by Sephadex G12 (comparison with known $K_{\mathrm{av}}$ values of standard substances; Liebermann \& Oertel, 1983), by hydrolysis and identification of the reaction products, as done for the analysis of the enzyme-bound intermediates, and by dansylation.

The results correspond to those of other multienzymes or multienzyme complexes which work by the 'thiotemplate mechanism' (Kleinkauf \& Koischwitz, 1978; Kleinkauf \& van Döhren, 1982). Synthesis of tentoxin probably also occurs by a polyfunctional multienzyme with a molecular mass of about $400 \mathrm{kDa}$. Tentoxin synthetase is localized at or in membranes and is sensitive to changes in the surrounding environment (Ramm et al., 1994b). The primary product of peptide synthesis is dihydrotentoxin, which is released probably by cyclization (Liebermann \& Ihn, 1988). The further conversion to tentoxin, independent of the first synthetase but probably contiguous in the membrane, is relatively low in the intact mycelium. The turnover of added radioactively labelled dihydrotentoxin in the system with mycelium pieces into tentoxin was detectable but only at $0.07 \%$ (Liebermann et al., 1992). Added labelled tentoxin was converted in dihydrotentoxin in vivo with a turnover rate of $0.03 \%$. The second stage of tentoxin synthesis is therefore reversible.

\section{ACKNOWLEDGEMENTS}

The authors thank H. von Döhren and his group at TU Berlin for the theoretical and practical support in the enzyme studies.

\section{REFERENCES}

Bradford, M. M. (1976). A rapid and sensitive method for the quantification of microgram quantities of protein using the principle of protein-dye binding. Anal Biochem 72, 248-254.

Brückner, B., Hänel, l., Hänel, F. \& Tröger, R. (1983). Einfluß von Phosphat auf die Bildung von Tentoxin durch Alternaria alternata (Fr.) Keissler. Z Allg Mikrobiol 23, 549-556.

Durbin, R. D. \& Uchytil, T. F. (1977). A survey of plant insensitivity to tentoxin. Pbytopathology 67, 602-603.

Edel, B., Brückner, B. \& Tröger, R. (1985). Einfluß von Phosphat und Inhibitoren auf das Wachstum und die Tentoxinbildung von Alternaria alternata (Fr.) Keissler. J Basic Microbiol 25, 155-160.

Gevers, W., Kleinkauf, H. \& Lipmann, F. (1968). The activation of amino acids for biosynthesis of gramicidin S. Proc Natl Acad Sci US A 60, 269-276.

Gevers, W., Kleinkauf, H. \& Lipmann, F. (1969). Peptidyl transfers in gramicidin $\mathrm{S}$ biosynthesis from enzyme-bound thioester intermediates. Proc Natl Acad Sci US A 63, 1335-1342.

Grable, C. I., Templeton, G. E. \& Meyer, W. L. (1966). Purification and partial characterization of the chlorosis toxin of Alternaria tenuis. Pbytopathology 56, 879.

Hänel, I. (1985). Untersucbungen qum Phosphat-und Acetateinfluß auf die Bildung des Phytoeffektors Tentoxin durch Alternaria alternata $(F r$. Keissler. Dissertation, Friedrich-Schiller-Universität, Jena.

Hänel, I., Liebermann, B., Brückner, B. \& Tröger, R. (1985). Einfluß von Acetat auf die Bildung des Phytoeffektors Tentoxin durch Alternaria alternata (Fr.) Keissler. J Basic Microbiol 25, 365-371.

Keller, U. (1987). Actinomycin synthetases. Multifunctional enzymes responsible for the synthesis of the peptide chains of actinomycin. J Biol Chem 262, 5852-5856.

Keller, U. \& Kleinkauf, H. (1977). Studies of the biosynthesis of actinomycin in protoplasts from Streptomyces antibioticus. Arch Biochem Biophys 184, 111-124.

Kleinkauf, H. \& von Döhren, H. (1982). A survey of enzymatic peptide formation. In Peptide Antibiotics - Biosynthesis and Function, pp. 3-21. Edited by H. Kleinkauf et al. Berlin, New York: Walter de Gruyter.

Kleinkauf, H. \& Koischwitz, H. (1978). Peptide bond formation in non-ribosomal systems. In Progress in Molecular and Subcellular Biology VI, pp. 59-112. Edited by F. E. Hahn. Berlin, Heidelberg, New York: Springer Verlag.

Koncewicz, M., Mathiaparanam, P., Uchytil, T. F., Sparapand, L., Tam, J., Rich, D. H. \& Durbin, R. D. (1973). The sequence and optical configuration of amino acids in tentoxin. Biochem Biophys Res Commun 53, 653-658.

Laemmli, U. K. (1970). Cleavage of structural proteins during the assembly of the head of bacteriophage T4. Nature 227, 680-685.

Lee, J. \& Agathos, S. N. (1989). Effect of amino acids on the production of cyclosporin A by Tolypocladium inflatum. Biotechnol Lett 11, 77-82.

Liebermann, B. (1989). Wirkstoffsynthese durch Alternaria alternata unter besonderer Berïcksichtigung cyclischer Peptide. Dissertation, Promotion B, Friedrich-Schiller-Universität, Jena.

Liebermann, B. \& Ihn, W. (1988). Dihydrotentoxin: a precursor of tentoxin or its degradation product? J Basic Microbiol 28, 63-70.

Liebermann, B. \& Oertel, B. (1983). Bildung und Isolierung des Phytotoxins Tentoxin aus Alternaria alternata. Z Allg Mikrobiol 23, 503-511.

Liebermann, B. \& Ramm, K. (1991). $N$-methylation in the biosynthesis of the phytotoxin tentoxin. Phytochemistry 30, 1815-1817.

Liebermann, B., Ihn, W., Baumann, E. \& Tresselt, D. (1988). Dihydrotentoxin and a related dipeptide produced by Alternaria alternata. Phytochemistry 27, 357-359.

Liebermann, B., Schuffenhauer, S. \& Ihn, W. (1991). Biosynthesis of tentoxin and dihydrotentoxin via protein turnover by Alternaria alternata. J Basic Microbiol 31, 51-57.

Liebermann, B., Ramm, K. \& Baumann, E. (1992). Die analytische Erfassung der cyclischen Tetrapeptide Tentoxin und Dihydrotentoxin und deren Bausteine. In Vom Organismus zum Molekül. Pbysiologische Prozesse, ibre Modellierung und Beeinflußbarkeit auf verschiedenen Ebenen, pp. 336-349. Edited by I. Dahse. FriedrichSchiller-Universität Jena: Universitätsverlag Jena.

van Liempt, H. (1988). Untersucbungen zur Biosynthese der $\beta$-LactamVorstufe $\delta$-(L- $\alpha-$ Aminoadipyl $)-L-C y s t e i n y l-D-V$ alin. Dissertation, Technische Universität, Berlin. 
Martin, J. F. \& Demain, A. L. (1980). Control of antibiotic biosynthesis. Microbiol Rev 44, 230-251.

Meyer, W. L., Templeton, G. E., Grable, C. E., Sigel, C. W., Jones, R., Woodhead, S. H. \& Sauer, C. (1971). The structure of tentoxin. Tetrabedron Lett 25, 2357-2360.

Mohr, B. (1958). Chloridbestimmung. In Kurze Anleitung zur Maßanalyse mit besondere Berücksichtigung der Vorschriften des D AB.6 und des Erg-B.6 (15 vervollständigte und erweiterte Auflage). In der Reihe Einleitung in die chemische Analyse, Bd. II, p. 341. Edited by L. Medicus \& W. Poethke. Dresden and Leipzig: Steinkopff.

Neuhoff, V. (1973). Micromethods in Molecular Biology, p. 85. Berlin, Heidelberg, New York: Springer Verlag.

Oertel, B. (1983). Untersuchungen zur Pbysiologie und Kinetik der Tentoxinbildung bei Alternaria alternata (Nee ex Fr.). Dissertation, Friedrich-Schiller-Universität, Jena.

Orvehed, M., Häggblom, P. \& Söderhäll, K. (1988). Nitrogen inhibition of mycotoxin production by Alternaria alternata. Appl Environ Microbiol 54, 2361-2364.

Ramm, K., Brückner, B. \& Liebermann, B. (1994a). Biosynthesis of the phytotoxin tentoxin. I. Synthesis by protoplasts of Alternaria alternata. Appl Biochem Biotechnol 48 (in press).

Ramm, K., Ramm, M., Liebermann, B. \& Reuter, G. (1994b). Biosynthesis of phytotoxin tentoxin. II. Cell-free biosynthesis of tentoxin. First evidence on the localization of toxin synthesis in Alternaria alternata. Appl Biochem Biotechnol 48 (in press).

Roskoski, R., Jr, Gevers, W., Kleinkauf, H. \& Lipmann, F. (1970). Tyrocidine biosynthesis by three complementary fractions from Bacillus brevis (ATCC 8185). Biochemistry 9, 4839-4845.
Russell, D. W. (1960). Ninhydrin as a reagent for $N$-methylamino acids. J Chromatogr 4, 251-252.

Schadler, D. L., Steele, J. A. \& Durbin, R. D. (1976). Some effects of tentoxin on mature and developing chloroplasts. Mycopathol 58, 101-105.

Sheu, J. \& Talburt, D. E. (1986). Stimulation of tentoxin synthesis by age-culture filtrates and continued synthesis in the presence of protein inhibitors. Appl Environ Microbiol 51, 368-372.

Steele, J. A., Uchytil, T. F., Durbin, R. D, Bhatnagar, P. \& Rich, D. H. (1976). Chloroplast coupling factor 1. A species specific receptor for tentoxin. Proc Natl Acad Sci US A 73, 2245-2248.

Templeton, G. E. (1972). Alternaria toxins related to pathogenesis in plants. In Microbial Toxins 8, pp. 169-192. Edited by A. Ciegler, S. Kadis \& S. J. Ajl. London: Academic Press.

Woodhead, S. H., Templeton, G. E., Meyer, W. L. \& Lewis, R. B. (1975). Procedure for crystallization and further purification of tentoxin. Phytopathology 65, 495-496.

Zhang, J., Wolfe, S. \& Demain, A. L. (1989). Carbon source regulation of ACV-synthetase in Cephalosporium acremonium $\mathrm{C}-10$. Curr Microbiol 18, 361-367.

Zocher, R., Salnikow, J. \& Kleinkauf, H. (1976). Biosynthesis of enniatin B. FEBS Lett 71, 13-17.

Zocher, R., Nihira, T., Paul, E., Madry, N., Peeters, H., Kleinkauf, H. \& Keller, U. (1986). Biosynthesis of cyclosporin A: partial purification and properties of a multifunctional enzyme from Tolypocladium inflatum. Biocbemistry 25, 550-553.

Received 4 January 1994; revised 15 June 1994; accepted 3 August 1994. 